\title{
Tolerance and Truth in Intercultural Dialogue: Some Reflections
}

\author{
Elisabeth MeILHAmmer, JenA
}

\section{The Problem of Intercultural Dialogue}

It is only in the last few decades that "interculturality" and "intercultural dialogue" have become popular terms both in everyday and scientific discourse, while the problems referred to by these terms of course are far from being new. This may indicate an increased consciousness (1) of the omnipresence of intercultural contacts in the wake of globalization and (2) of the assumed or experienced detrimental consequences - for individual and social life as well as for democracy and global peace - connected with the failure of intercultural contacts. Thus, 'interculturality' and 'intercultural dialogue' have become symbols for human togetherness, and given the acknowledged importance of these concepts, academic disciplines dealing with human relations, such as philosophy, psychology or education, can no longer exclude them from the argumentative contexts of their respective fields. Consequently, there is a growing need to clarify the problem of interculturality, to examine its meaning, content and implications. Today interculturality must be a central subject matter of historically and/or systematically expounded theories in the humanities and in the social sciences - a requirement which is to be reflected within the various academic disciplines and in the interdisciplinary framework, taking into consideration the historical and the present social, political, and socio-structural forms and tendencies of interculturality, as well as its effects on individuals and individual identity.

In connection with this, the question must be asked how interculturality and intercultural dialogue relate to other fundamental dimensions of human thought and human behavior, two of which stand in the focus of attention of this paper, namely, tolerance and truth. It is asked whether intercultural dialogue with its need for tolerance - for admitting different legitimate ways of thinking and acting - is compatible with the pursuit of truth, which seems to require from the start that there can only be one true way of thinking and acting. 
Before trying to answer this question, we need to take a look at the central terms. As for "culture", there are some two hundred different attempts to determine its content. Obviously, "culture" is a term that people use in very different manners, and we cannot assume that there is a universally shared understanding of what is meant by it. For example, in the German language area, there is at least a tendency to focus on ethnicity and geography when speaking of cultures, whereas in the Anglo-Saxon language area, also culture-generating variables other than ethnicity and geography are stressed, such as generation, gender, affiliation, and social status (cf. Pedersen 2004, 3). What seems most significant is that culture, on the one hand, is manifested by artifacts (in this form, it is conserved and fixed) and that, on the other hand, it is a mental disposition shared by a group of people, which is relevant for their identity concepts and their perceptions of other people (and therefore dynamic). For intercultural relationships, the last sense of culture is probably the more important one, and hence it seems proper to follow Helen Spencer-Oatey (2000, 4), who describes "culture" as "a fuzzy set of attitudes, beliefs, behavioural conventions, and basic assumptions and values ... which influence their behaviour and their interpretations of the meaning of other people's behaviour."

The term "interculturality", in turn, refers to a relationship between two or more cultures, for which their difference and similarity, openness and delimitation are constitutive (cf. Friedenthal-Haase 1992, 16; FriedenthalHaase 2002, 498). In this sense, we can speak of "interculturality" only if the relationship between cultures is neither directed towards a complete homogenization nor a complete separation, exclusion or even extinction, and only if at least a minimum of differing and having in common is acknowledged in principle and possible in reality (cf. ibid.).

This given, we can say that an intercultural dialogue is a dialogue that displays the features of interculturality just described. The partners in such a dialogue are likely to think differently - at least in part - about what is appropriate and what is not, and also about what is right and what is wrong. Thus, intercultural dialogue starts out with a relationship between persons who originally or "naturally" (or "unreflectedly"), as judged on the basis of their frameworks of value and interpretation, do not fully understand each other. The challenge that is structurally inherent in intercultural dialogue - a relationship characterized by basic mutuality! - has its roots in a lack of mutual understanding.

The aim of intercultural dialogue, in a most general sense, is to overcome this "natural" situation of non-understanding - and to avoid confron- 
tation which is due to non-understanding. Intercultural dialogue can be seen as an answer to the challenges entailed by cultural diversity in our age of globalization, above all as an answer to the widespread fear that cultural diversity is not an enrichment of, but a threat to identity and that it leads to cultural clash. Perhaps it is even true that intercultural dialogue has, in response to this fear, become a new paradigm for global relations (cf. Stiftung Entwicklung und Frieden 2001, 36 and 107-170), which is made visible and promoted on a broad basis. An example for the propagation of this new paradigm is the proclaiming of the year 2008 as the "European Year of Intercultural Dialogue" by the European Union; another example is the designation of the year 2001 (which, ironically, will always be remembered best by the terrorist attacks of September 11) as the "Year of Dialogue Among Civilizations" by the United Nations.

\section{Intercultural Dialogue and the Question of Tolerance}

The way in which the aim of intercultural dialogue is reached must neither involve an explicit or implicit superiority claim of one of the participants over the other, nor neglect existing cultural differences. The aim of intercultural communicative efforts, namely to maintain the difference between cultural systems and to come to a mutual understanding at the same time, is therefore difficult to achieve and may even seem self-contradictory.

But this aim is, as a matter of fact, not self-contradictory; the very idea of interculturality as mutuality requires from the start, as mentioned above, at least a minimum of differing and of having in common, without any detriment to the coherence of that idea. Interculturality is directed both towards the general, which the dialogue partners have in common, and towards the specific, in which they differ. Intercultural dialogue presupposes that some common ground between the cultures can be identified, which serves as a basis for a mutual clarification of the differences. Consequently, the possibility of a dialogue across the boundaries of cultures depends on the assumption that there are valid transcultural values which are applicable to all partners in the intercultural dialogue.

An important key to reaching the aim of intercultural dialogue is to reject any kind of centrism (for example, ethnocentrism) - to reject the universalization of a point of view which is only of particular validity - and to embrace tolerance. However, since value systems constitute cultures to a large degree, the pursuit of tolerance is often taken to consist in acknowledging that no culturally based value system can be objectively superior to 
any other such value system. This means that either there is no objective standard of comparison for the different cultural value systems, or that, from an objective point of view, they are all of equal standing. In any case, it seems that the pursuit of tolerance demands that there is no objective basis for judging the value system of one culture to be better than that of another culture. Moreover, it seems that only this absence of objectivity and the acceptance of it can be the source of tolerance. In consequence, successful intercultural dialogue seems to depend on a relativist approach and on abstaining from ranking culturally different values according to objective importance and truth.

Now, is it indeed detrimental to intercultural dialogue to adhere to the assumption, and to express it, that certain values on one side of a cultural divide are objectively right, respectively important, whereas values on the other side of that divide are objectively wrong, respectively unimportant? I would like to consider this question. Doing so involves, centrally, a clarification of the relationship between tolerance and truth and of the implications of this relationship for intercultural dialogue.

Firstly, the Latin root of "to tolerate" reminds us that it means to endure something we dislike, disagree with or disapprove of. Consequently, it does not make sense to talk of toleration when expressing, say, agreement, pleasure, or untroubled friendship. Secondly, being tolerant implies being in a position to change something about the situation disliked, disagreed with or disapproved of. This indicates the voluntary nature of the attitude of tolerance; nobody can be forced to be tolerant. And thirdly, tolerance must be distinguished from indifference. We are not tolerant if we do not care about a matter; we are only tolerant in cases where we do care, and do not share an expressed opinion, view, attitude, custom or habit, but still put up with it.

Moreover, some theorists have rightly claimed that it is not enough to define tolerance negatively as the absence of intolerance, as a concept of mere endurance, but that it needs to be complemented by a positive dimension: of actively creating human reality by recognizing and esteeming difference. The UNESCO Declaration of Principles on Tolerance from the year 1995 (article 1) stresses that "[t]olerance is respect, acceptance and appreciation of the rich diversity of our world's cultures, our forms of expression and ways of being human. (...) Tolerance is harmony in difference. (...) Tolerance is not concession, condescension or indulgence. (...) It means that one is free to adhere to one's own convictions and accepts that others adhere to theirs. It means accepting the fact that human beings, 
naturally diverse in their appearance, situation, speech, behaviour and values, have the right to live in peace and to be as they are. It also means that one's views are not to be imposed on others."

Obviously, tolerance is a virtue that is needed for intercultural dialogue. But how far does it go? Does it imply tolerating all cultural differences equally, not only enduring but esteeming all of them? Is it illegitimate, from a tolerant point of view, to pass judgments on other cultures? And does tolerating cultural features or practices other than my own exclude my believing that my own culturally determined beliefs and practices are better than the ones that I do not share?

\section{Intercultural Dialogue and Cultural Relativism}

Many advocates of intercultural dialogue adopt a non-judgmental cultural relativist standpoint, claiming that value judgments about other cultures are to be avoided. The argument for this position runs as follows: Values and ideals are applicable only within the particular cultures which acknowledge them. As there are neither universal nor transcultural values, cultures can only be approached from within. It is impossible to adopt a culture-neutral standpoint or to find an objective standard for comparing values and evaluating ideals. Therefore, it cannot be shown that one value is objectively superior to another. Since a person can never leave the perspective of his or her own culture, judging the values of another culture amounts to cultural imperialism and cannot be morally justified. It is, therefore, required of all cultures to tolerate - in the cultural relativist sense - all other cultures and their respective value systems (cf. Khin Zaw 1996, 128; Siegel 1999, 393).

It is interesting to note that this argument which includes the rejection of all forms of universal value claims nevertheless makes universal value claims: demanding of all cultures to tolerate all other cultures and their respective value systems is, in fact, a universal value claim, just as is the claim that cultural imperialism is simply wrong (and not only from the perspective of a certain culture). The argument is, therefore, incoherent: it invokes transcultural values while it denies the existence of such values. There is only one logical way out of this situation that allows one to remain an advocate of intercultural dialogue: to give up the assumption that all values are culture-relative.

There are some other problems connected with the position that all values and ideals are culture-relative and cannot, and must not, be judged from the outside. 
Firstly, from this relativist perspective it is possible to express one's own beliefs, but it is impossible to claim that what one believes to be right is applicable across cultural boundaries. Rather, judgment on a given cultural practice, for example, can only be passed relative to the cultural context to which one belongs. Therefore, I cannot claim that female genital cutting is wrong as such. As I cannot judge another culture objectively, all I can do is claim that from my cultural perspective, female genital cutting is wrong. We can easily see that such criticism is without any bite, since it treats the question at issue as if it were a mere question of cultural taste. It can easily be silenced by the opposite viewpoint: "But in my culture, female genital cutting is a good thing; basta." The dialogue comes to an end here (de gustibus non est disputandum). Clearly, the relativist position does not allow the claim that violations of human rights are objectively wrong, as these violations must, according to that position, always be seen in a cultural context. One could also ask, "Why condemn the Nazis? The things they did were just an expression of their culture, which must not be judged from the outside", and there could be no valid objection to this if relativism were right. At this point, most of us will intuitively feel that something is wrong with the relativist position. But we can only reconcile our intuition with our philosophy if we acknowledge that some values are valid beyond the boundaries of any particular culture - namely, those values which belong to the sphere of "the right" (for example, human dignity and human integrity) rather than to the sphere of "the good" (cf. Rawls 2001), those values which can be generalized and refer to "moral questions" that can be decided rationally, rather than to "evaluative questions" of a particular good life that can only be discussed within the framework of a concrete historical form of life or an individual way of life (cf. Habermas 1991, 39).

Secondly, the cultural relativist standpoint cannot explain the noncoercive influence which different cultures exert on one another and have always exerted in the history of cultural development (cf. Nussbaum 2000, 48-49). If the assumption is kept up that there are no transcultural values, then the fact that cultures have always developed in exchange with other cultures must be seen exclusively as a mere question of power and domination, so that those values which spread from one culture to another cannot properly become values of this other culture but must always remain externally imposed and alien to it. It is undeniable that in the history of mankind there are many cases where values have been forced upon a weaker culture by a stronger culture. But what is of interest here are cases - and such cases exist - where one culture recognizes the - transcultural - truth or su- 
periority in a feature of another culture and therefore adopts it, in other words, cases where one culture learns from another culture in a noncoercive way.

An important point of clarification needs to be made. Radical and moderate cultural relativists agree that there are no transcultural values in the sense of culture-absolute values, whereas there are of course culturerelative values. Radical cultural relativists hold in addition that different cultures never ever have any values in common; this is usually accompanied by the assertion that no culture can truly understand any other culture. The question that must be asked here is how, given these assumptions, intercultural dialogue can be possible at all - since an intercultural relationship, as was said above, needs at least some common ground. Moderate cultural relativists, in their turn, hold that certain values can indeed be shared (accepted) by different cultures. Thus, moderate cultural relativists can, in a sense, believe in transcultural values - but this is not the sense of transcultural value which is relevant here. Consider that transcultural values in the cultural relativist sense are only valid for the accepting cultures, not, however, valid independently of acceptance or non-acceptance. Therefore, they cannot be employed in criticizing another culture - if this criticism is to be more than a mere expression of how one sees matters from one's own cultural viewpoint.

Let's assume (cf. in a similar sense Harris 1982, 224) that Mary is a tolerant person who lives in a democratic society and is committed to the idea of equality - equality regarding both individuals and cultures. But what if one of these cultures - culture $\mathrm{C}$ - does not honor the idea of equality and does not equally respect all persons? From Mary's point of view, valuing the equality of individuals requires her to criticize, or even condemn, the discriminatory features of this other culture, while at the same time valuing the equality of cultures requires her to refrain from cultural criticism. How might Mary escape from this dilemma? According to cultural relativism, she must make the following declaration: "From my point of view, I disapprove of the discriminatory practices of culture $\mathrm{C}$, but at the same time, I hold that, from my point of view, culture $\mathrm{C}$ is as acceptable as any other culture." This is obviously not a plausible way out of Mary's dilemma. The only plausible way out for Mary is to draw limits to tolerance and to go ahead with criticizing the discriminatory features of culture $\mathrm{C}$ without at the same time letting $C$ be as acceptable as any other culture. But this implies the recognition on Mary's side that there are transcultural values in the culture-absolute sense, or in other words: that there is objective truth 
regarding values. At the same time, these transcultural values constitute what must be held in common for entering into an intercultural relationship.

\section{A Reconciliation of Tolerance and Truth in Intercultural Dialogue}

But does not the assumption of the truth of one's own convictions stand in the way of dialogue, even the ability for dialogue? And worse than that: does not this assumption lead to violence? Isaiah Berlin is right when he states that in the history of mankind "[f]ew things have done more harm than the belief on the part of individuals or groups (or tribes or states or nations or churches) that he or she or they are in sole possession of the truth" (Berlin 2001, 12, emphasis in the original), as this belief "makes one certain that there is one goal \& one only for one's nation or church or the whole of humanity, \& that it is worth any amount of suffering (particularly on the part of other people) if only the goal is attained" (ibid.). The problem Berlin draws attention to, however, is not the question whether there is objective truth at all; rather, he criticizes a certain manner of relating oneself to truth: the manner of presumptuously claiming that one is already in the possession of the whole truth, or on the sole way to truth, without allowing the possibility of error (the evil implication being that differing positions are to be despised or even extinguished). In fact, it is this arrogant and ignorant (and perhaps fundamentally confused and insecure) - attitude that is the enemy of tolerance.

Moreover, there are two objections to the idea that assuming the truth of one's own convictions per se prevents tolerance:

(1) The assumption that one must (try to) suppress, or at least interfere with, a conception of the good that one believes to be wrong can only be upheld if the deontic judgment - the belief that the conception is wrong is also a responsibility judgment - a belief that it is mandatory to suppress the conception (cf. Wren 1991, 144-145; Churchill 1997, 204). In a pluralist society, this suppression can only be justified where the transcultural values of "the right" are at stake. In all other cases, the deontic judgment must be distinguished from the responsibility judgment, and it is perfectly consistent both to believe that a person $\mathrm{A}$ is wrong regarding $X$ (e.g., a certain religious belief) and to deny that any other person has the right and the responsibility to prevent A from exercising $X$. On the contrary: a democratic society stands in need of a plurality of views and conceptions of the good life; and a humane and enlightened society will stress the individual's 
capacity and right to decide for herself whether to adhere to a certain conception of the good or not.

(2) The assumption that one's own beliefs are true need not lead to a dogmatic or to an arrogant attitude - the attitude of considering oneself the sole possessor of truth. On the contrary, the Socratic wisdom that admits not to know, while it acknowledges objective truth and provisionally considers its convictions to be true, proves to be a rather realistic approach in relating oneself to the world. Our age, which has often been claimed to be an age of knowledge, can with equal right be characterized as an age of ignorance and uncertainty. No one can justify his or her beliefs completely; there will always remain assumptions that cannot be shown to be true and, likely enough, some of them are false. Thus, the holding of a belief in the right way has a seemingly paradoxical form: When we believe something in the right way, we certainly assume (perhaps emphatically) that what we believe is true - and not only true from our own point of view -, but at the same time we accept the possibility that we could be wrong. This modest attitude allows us to see ourselves as permanent searchers for truth instead of permanent possessors of truth, and thus to see also others as searchers for truth, and leads us to an insight which is very important for intercultural dialogue and which has long been recognized by protagonists of the dialogical relation, as for example, by Martin Buber. It is the insight that there are many paths to truth. Although the whole truth can never be fully grasped, each path can lead, so to speak, to a piece of the truth, which can be grasped. According to Martin Buber, the lines that lead to the different aims of all true searchers of truth, if extended beyond their particular aims, intersect in a higher sphere, which Buber $(1953,345)$ calls "the truth of God". According to Buber, education is essential for making this idea palpable; because it is the educational process which renders the intersection of the lines visible and experienceable; the different lines cross, and where they cross, human encounter can take place and true dialogue (cf. Meilhammer 2005, 174-175). Hence, in the educational process, not only "the sheer otherness of things in the world" can be learned, which "extends to recognition of the otherness of other cultures" (Standish 2006, 98), but also the experience of a common ground underlying the cultural differences.

The two above-described objections against the widespread idea that truth and tolerance are inimical to each other, suggest that the so-called paradox of toleration (cf. Raphael 1988, 139; Mendus 1989, 18-21; Langerak 1997, 116) can be solved: There is a plausible answer to the 
question why one should tolerate something (instead of trying to prevent it) though one is genuinely convinced that it is truly wrong. There are three good reasons for toleration: (1) It is a person's right - qua being a person to have her own convictions (irrespective of other persons approving of these convictions or not); (2) these other convictions - provided they respect certain culture-absolute transcultural values, most importantly the fundamental human rights - can legitimately be considered as the expression of a particular path to (a piece of) truth; and (3) one's own convictions could be wrong, although one cannot see this now, and perhaps never will. Thus, intercultural dialogue is more than just a confrontation, or indifferent expounding, of the different perspectives of different cultures. Something can occur which, from a cultural relativist stance, cannot be envisaged to the full extent of its meaning: genuine intercultural encounter - and intercultural learning - can take place, which can enrich one's own value system (by new truth) and can also challenge it (by putting into question the truth of beliefs so far held unquestioningly). One will have to legitimize one's own point of view. ${ }^{1}$ The perspective of the other can be the touchstone for one's own perspective, which may pass this test, or may also have to be modified. This modest and self-critical attitude leads to nonrelativist tolerance. It points to an understanding of intercultural dialogue that reconciles tolerance and truth. ${ }^{2}$

\section{REFERENCES}

Berlin, I. 2001 "Notes on Prejudice" [1981], The New York Review of Books, 48, 16 (Oct.18), 12.

Buber, M. 1953 "Geltung und Grenze des politischen Prinzips", in M. Buber, Hinweise: Gesammelte Essays, Zürich: Manesse Verlag, 330-346.

Churchill, R.P. 1997 "On the Difference between Non-Moral and Moral Conceptions of Toleration: The Case for Toleration as an Individual Virtue", in M. Amin

\footnotetext{
${ }^{1}$ John Stuart Mill $(1992,51 \mathrm{f})$ remarks, with respect to the toleration of different opinions, that a diversity of views promotes truth, because each of these views (though they may be false) can contain "a portion of truth"; moreover, instead of holding our own opinions as simple prejudices, views that differ from our own views will compel us to defend what we think is true, thus providing us with a better grasp of it.

${ }^{2}$ I would like to thank Kathrin Hönig (University of Zurich, Switzerland) for her pertinent comments on an earlier draft of this paper.
} 
Razavi and D. Ambuel (eds.), Philosophy, Religion, and the Question of Intolerance, Albany: State University of New York Press, 189-211.

Friedenthal-Haase, M. 1992 "Erwachsenenbildung und Interkulturalität: Zeitgemäße Perspektiven einer jungen Disziplin", in M. Friedenthal-Haase (ed.), Erwachsenenbildung interkulturell, Frankfurt (Main): Pädagogische Arbeitsstelle des Deutschen Volkshochschul-Verbandes, 13-22.

- 2002 "Interkulturalität als Idee und Form von Bildung: Zu Wegmarken aus der geschichtlichen Entwicklung vom 18. zum 20. Jahrhundert", in M. FriedenthalHaase, Ideen, Personen, Institutionen: Kleine Schriften zur Erwachsenenbildung als Integrationswissenschaft, München and Mering: Rainer Hampp Verlag, 497512 .

Habermas, J. 1991 "Was macht eine Lebensform rational?", in J. Habermas, Erläuterungen zur Diskursethik, Frankfurt (Main): Suhrkamp Verlag, 31-48.

Harris, J. 1982 “A Paradox of Multicultural Societies", Journal of Philosophy of Education, 16, 223-233.

Khin Zaw, S. 1996 "Locke and multiculturalism: toleration, relativism, and reason", in R.K. Fullinwider (ed.), Public education in a multicultural society: Policy, theory, critique, Cambridge et al.: Cambridge University Press, 121-155.

Langerak, E. 1997 "Disagreement: Appreciating the Dark Side of Tolerance", in M. Amin Razavi and D. Ambuel (eds.), Philosophy, Religion, and the Question of Intolerance, Albany: State University of New York Press, 111-124.

Meilhammer, E. 2005 "Wertneutralität und Bildung bei Martin Buber", in M. Friedenthal-Haase and R. Koerrenz (eds.), Martin Buber: Bildung, Menschenbildung und Hebräischer Humanismus, Paderborn et al.: Ferdinand Schöningh, 149-180.

Mendus, S. 1989 Toleration and the Limits of Liberalism, Atlantic Highlands: Humanities Press.

Mill, J.S. 1992 "On Liberty" [1859], in J. S. Mill, On Liberty and Utilitarianism, New York, Toronto: Everyman's Library Alfred A. Knopf, 1-110.

Nussbaum, M. 2000 Women and Human Development: The Capabilities Approach, Cambridge: Cambridge University Press.

Pedersen, P.B. 2004110 experiences for multicultural learning, Washington DC: American Psychological Association.

Raphael, D.D. 1988 “The Intolerable", in S. Mendus (ed.), Justifying Toleration: Conceptual and Historical Perspectives, Cambridge et al.: Cambridge University Press, 137-153.

Rawls, J. 2001 "The Priority of Right and Ideas of the Good" [1988], in J. Rawls, Collected Papers, ed. by S. Freeman. Fourth printing, Cambridge, MA and London: Harvard University Press, 449-472.

Siegel, H. 1999 "Multiculturalism and the Possibility of Transcultural Educational and Philosophical Ideals", Philosophy, 74, 387-409.

Spencer-Oatey H. 2000 Culturally speaking. Managing rapport through talk across cultures, London: Continuum.

Standish, P. 2006 "Toleration, multiculturalism and mistaken belief", Ethics and Education, 1, 79-100. 
Stiftung Entwicklung und Frieden (ed.) 2001 Brücken in die Zukunft: Ein Manifest für den Dialog der Kulturen, Frankfurt (Main): S. Fischer Verlag.

Wren, T.E. 1991 Caring about Morality: Philosophical Perspectives in Moral Psychology, Cambridge, Mass.: The MIT Press. 